\title{
Customer Decision-making Processes and Motives for Self- service Technology Usage in Multi-channel Hospitality Environments
}

\author{
Petranka Kelly \\ Technological University Dublin, petranka15@gmail.com \\ Jennifer Lawlor \\ Technological University Dublin, jennifer.lawlor@tudublin.ie \\ Michael Mulvey \\ Technological University Dublin
}

Follow this and additional works at: https://arrow.tudublin.ie/tfschhmtart

Part of the Social and Behavioral Sciences Commons

\section{Recommended Citation}

Kelly, P., Lawlor, J. \& Mulvey, M. (2013) Customer Decision-making Processes and Motives for Self-service Technology Usage in Multi-channel Hospitality Environments, Int. J. Electronic Customer Relationship Management, Vol. 7, No. 2, 2013. doi:10.1504/IJECRM.2013.056491

This Article is brought to you for free and open access by the School of Tourism \& Hospitality Management at ARROW@TU Dublin. It has been accepted for inclusion in Articles by an authorized administrator of ARROW@TU Dublin. For more information, please contact arrow.admin@tudublin.ie, aisling.coyne@tudublin.ie, gerard.connolly@tudublin.ie.

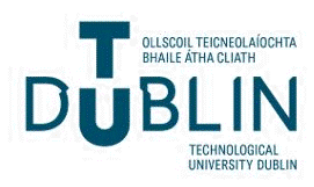




\title{
Customer decision-making processes and motives for self-service technology usage in multi-channel hospitality environments
}

\author{
Petranka Kelly*, Jennifer Lawlor and \\ Michael Mulvey
}

Dublin Institute of Technology, Sackville Place, Dublin 1, Ireland

E-mail: petranka.kelly@mydit.ie

E-mail: jennifer.lawlor@dit.ie

E-mail: michael.mulvey@dit.ie

*Corresponding author

\begin{abstract}
The contemporary hospitality service industry is changing with the introduction of new self-service technologies (SSTs) and their rapid adoption by customers. Examples of SSTs include hotel reservation websites, self check-in kiosks and mobile telephone service applications. The introduction of these electronic channels for communication with customers offers further opportunities for customer relationship management if customers choose to interact with them. Therefore, the aim of this paper is to understand the customer decision-making processes and underlying motivations for SST usage in multi-channel hospitality service environments. The data collection method employed was short qualitative interviews with 133 passengers at the departure area of an international airport. The findings contribute to an understanding of how and why customers use SSTs, which is critical from an eCRM perspective, in that many sectors of the hospitality industry may encourage or indeed require customers to use SSTs. As a result, this element of chosen/forced usage may have a huge impact on the user-company relationship.
\end{abstract}

Keywords: self-service technologies; SSTs; hospitality customer behaviour; customer management; multi-channel services; services marketing.

Reference to this paper should be made as follows: Kelly, P., Lawlor, J. and Mulvey, M. (2013) 'Customer decision-making processes and motives for self-service technology usage in multi-channel hospitality environments', Int. J. Electronic Customer Relationship Management, Vol. 7, No. 2, pp.98-116.

Biographical notes: Petranka Kelly is a PhD student in the College of Arts and Tourism at the Dublin Institute of Technology, Ireland. Her research focuses on customer participation in self-service technologies within the hospitality and tourism sector. She has presented papers at a number of international conferences and research events. Her paper entitled, 'Customer Participation in Self-Service Technologies in the Tourism Sector' won second prize for the Best PhD Proposal in January 2011 at the Annual International Federation for IT and Travel and Tourism Conference in Innsbruck, Austria.

Jennifer Lawlor is a Lecturer in Strategic Management at undergraduate and Masters' level at the Dublin Institute of Technology. She has presented a number of conference papers in the USA, UK, and Europe in the area of inter-firm collaboration and cooperation. Her research interests include organisational change, corporate culture, and service design and delivery. 


\section{Introduction}

The advance of information technology in the past decade has leveraged the vast implementation of self-service technologies (SSTs) in the broader hospitality service industry (Castro et al., 2010; Kim et al., 2012). The development of various SST options have enriched the company portfolio of service delivery channels; thus, offering opportunities for cheaper and more efficient service provision and more satisfied customers (Meuter et al., 2000). However, customer behaviour towards SSTs has been predominantly researched in terms of the factors that affect consumers in their usage or intentions to use SSTs (Gelderman et al., 2011; Lin and Hsieh, 2007). A major shortcoming of SST adoption factor research, from the perspective of the customer, is the assumption that once SSTs are used by customers, they will then proceed to use them regularly on all occasions thereafter (Wang et al., 2012). In fact, a customers' attitude towards a given SST, may be a good predictor of SST usage intentions, but it may also be mediated by situational factors which may affect the actual usage behaviour (Wang et al., 2012). Therefore, whilst other studies to date have tended to focus on the factors affecting SST adoption by customers, this paper explores a different avenue by examining customer decision-making processes and motivations for SST usage in multi-channel hospitality service environments. An understanding of how and why customers use SSTs is critical from an eCRM perspective, in that many sectors of the hospitality industry may encourage or indeed require customers to use SSTs. As a result, this element of chosen/forced usage may have huge impact on the user-company relationship.

This paper commences by offering a review of the extant research into customer behaviour towards SSTs and customer choice of channels in multi-channel services. The research methodology section explains how the data was collected and analysed, followed by presentation of the findings with supporting illustrative quotes from the data. The discussion section locates and compares the findings from this study within the current body of research on customer decision-making and motivations for SST usage. The paper concludes with the limitations of this study and the suggestions for further research.

\section{Research into factors affecting SST adoption}

SSTs are attracting research attention in services marketing and management, because when they are implemented successfully, they have proven to offer efficient and effective service standards, often without any traditional employee involvement (Curran and Meuter, 2005). The tourism and hospitality industry has been transformed by technologies enabling consumers to search, customise and purchase services online (Buhalis and Law, 2008). Onsite SSTs, such as ticketing kiosks, self check-in facilities and interactive travel attraction guides, have contributed to higher quality, faster and cheaper services at lower operational costs (Egger and Buhalis, 2008). 
The need to understand consumer decisions regarding SSTs have justified the research attention into the factors affecting consumer adoption of SSTs (Curran and Meuter, 2005; Gelderman et al., 2011). A review conducted by the authors of publications relating to SST adoption from the past ten years identified over 60 publications in peer reviewed journals. This review produced a number of SST adoption factors that were researched in various contexts for different SST types. These factors range from user characteristics and attitudes (Dabholkar and Bagozzi, 2002; Gelderman et al., 2011; Lin and Chang, 2011; Meuter et al., 2005; Walker and Johnson, 2006), consumer demographics (Dean, 2008; Lee et al., 2010; Nilsson, 2007), technology attributes (Meuter et al., 2005) to situational factors (Dabholkar and Bagozzi, 2002; Gelderman et al., 2011; Simon and Usunier, 2007; Wang et al., 2012). Seven of the most often researched SST adoption factors in the literature include demographic variables (e.g., age, gender, income and education), trust, perceived risk, perceived ease of use, perceived usefulness, technology readiness and preference for personal contact (Kelly et al., 2011).

Baron et al. (2006) and Gelderman et al. (2011) suggest that the widely popular empirical testing of factors predicting the adoption of technology by consumers is reaching saturation. There is a need to explore how consumers use the technology that they have adopted and to understand the nuances of consumer behaviour which are difficult to capture with standard questionnaires (Baron et al., 2006; Lin and Chang, 2011). Furthermore, Wang et al. (2012) suggest that SST research has predominantly studied the adoption of SST interfaces in isolation from contextual factors such as the other available channels to obtain the particular service. While SST adoption research provides a base for explaining customer reasons and factors for SST trial, it does not account for the fact that SST adoption may not mean that those customers will prefer the SST option on all occasions (Wang et al., 2012). The optimal service situation would be to have a number of service delivery channels from which the customer may choose, but the problem is that maintaining too many channels may affect the profits of the company and the consistency of service quality across channels (Bergman and Thelen, 2004). The purpose of SST adoption factor research is to understand how customers can be converted to use the SST option, but full SST service is still unthinkable for most contemporary service companies (Reinders et al., 2008). Therefore, Reinders et al. (2008) suggest as an avenue for further research, the exploration of what is the optimal level of SST provision and the extent to which companies should avoid imposing more SST options on their customers. The contemporary hospitality service landscape is characterised by various SST options alongside the more traditional personal options (Kim et al., 2012). This mixture of service delivery channels characteristic of the hospitality industry makes it an ideal context for studying how customers use SSTs in a multi-channel, multi-provider service environment.

\section{SSTs in multi-channel service environments}

Multi-channel service environments are characterised by the provision to customers of more than one service delivery channel, i.e., personal service, telephone channel, company website and onsite kiosks (Neslin and Schankar, 2009). SST options are often part of multi-channel service environments, although SST research has predominantly studied specific SSTs in isolation (Wang et al., 2012). Wallace et al. (2004) differentiate 
between two types of multi-channel environments, i.e., channel mix and channel integration.

Channel mix means the offering of a number of personal or SST options of access to the service (Wallace et al., 2004). For example, an airline may offer its passengers to check-in online, via a smart phone, at a check-in kiosk or at the personal check-in desk. Those channels offer the same incremental service, so the customer needs to select the optimal channel among the offered options. If one channel outperforms the others, there may be a case of channel cannibalisation or substitution (Van Birgelen et al., 2006). This rivalry between channels is confirmed by Curran et al. (2003), who found that an unfavourable attitude towards the personal service option leads to a more favourable attitude towards the SST option and vice versa. Similarly, Van Birgelen et al. (2006) found that for routine banking services, when two channels deliver the same service, one may substitute the other, i.e., a well performing ATM or online banking may substitute for the personal service. In this situation, the satisfaction with the SST option weakened the effect of satisfaction with the personal option on behavioural intentions (Van Birgelen et al., 2006).

The strategy of channel integration (Wallace et al., 2004) captures the provision of complementing service options throughout the service delivery. In this way, each channel offers added benefits, or eliminates the disadvantages of other company channels (Wallace et al., 2004). For example, a retail customer may search for a product online, order it in store from a kiosk and have it delivered to their home, or they may check stock online, pay online and collect in store if they prefer to try it on (Bergman and Thelen, 2004). In this situation, a company needs to achieve consistency in price and promotion across channels and maintain an integrated database (Bergman and Thelen, 2004). Companies may find investing in multi-channel optimisation profitable, as Neslin and Shankar (2009) found that multi-channel retail customers displayed higher levels of satisfaction and customer value. In the case of complementarity between channels, the satisfaction with the personal service strengthens the satisfaction with the SSTs and vice versa (Van Birgelen et al., 2006).

Multi-channel research has studied some aspects of customer behaviour in those environments. For example, the customer channel preference may depend on situational factors (Wang et al., 2012), or customer goals (Chatterjee, 2007) and motivations (Schroeder and Zaharia, 2008). The customer choice between on-site check-in kiosk at an airport or personal check-in desk may depend on situational factors, such as length of queue, perceived task complexity, other accompanying customers, or previous experience with the service (Wang et al., 2012). However, those situational influences may not be applicable to the internet and telephone SST option, which presents a research gap (Wang et al., 2012). The customer motives for channel usage of an integrated multi-channel retailer are researched by Schroeder and Zaharia (2008). The findings suggest that exclusive store users satisfy social needs, whereas online and catalogue users strive for independence and convenience, whilst customers who combine online information with purchase at the store, seek independence and risk reduction (Schroeder and Zaharia, 2008). As a limitation of the study, Schroeder and Zaharia (2008) suggest the fact that the multi-channel retailer was a well established, trusted national retailer, employing an integrated channel strategy, may have played a part in the customer decision. Therefore, future research may explore customer motives in other types of multi-channel environments, for example, motives such as seeking the lowest price or better deals were not explored in Schroeder and Zaharia's (2008) research. 
The desire to understand what drives customer usage of SSTs has initiated some limited research into the reasons for customer engagement. The reasons for customer usage of SSTs include cost savings (Meuter et al., 2003), convenience (Dabholkar et al., 2003; Liljander et al., 2006; Meuter et al., 2003), habit (Liljander et al., 2006), control and independence (Dabholkar et al., 2003; Liljander et al., 2006; Meuter et al., 2003) and the lack of other options (Meuter et al., 2003). Using SSTs can also provide some consumers with intrinsic benefits, such as feelings of independence and enjoyment (Dabholkar et al., 2003; Meuter et al., 2003). Some consumers even admitted using SSTs in order to avoid the personal contact with service employees (Dabholkar et al., 2003). Some of those identified reasons represent motives such as convenience, independence and cost savings, while habit and lack of other service delivery options may be regarded as conditions rather than motivations.

Customers may also avoid SSTs under the influence of certain de-motivations and service situations. The SST will be abandoned if consumers experience failure due to technology breakdown or customer mistake (Meuter et al., 2000). Some consumers may feel anxiety when using SSTs (Lee et al., 2010; Meuter et al., 2003) because they are intimidated by the complexity of the technology interface (Meuter et al., 2000), or they risk embarrassment if they cannot operate it successfully (Forbes, 2008). SSTs may be viewed as an inconvenience when perceived as arduous to operate or learn (Liljander et al., 2006). SSTs also require higher levels of consumer participation and responsibility, so they are perceived as riskier than personal services (Lee and Allaway, 2002). Even people who have favourable attitudes towards technology may avoid SSTs because they cannot replace the personal interaction (Dabholkar et al., 2003; Lee and Allaway, 2002), or they require a radical change in their consumer behaviour (Curran and Meuter, 2007).

The methodology employed by Dabholkar et al. (2003), Liljander et al. (2006) and Meuter et al. (2003) involved the inclusion of an open question in a questionnaire asking customers to state why they would use an SST. Questioning customers why they may act as they do may not produce a very deep understanding of their motivation (Thompson et al., 1989). Asking 'why' questions introduce abstract thinking on the part of the participant, putting them in the role of 'experts' on their motivation (Thompson et al., 1989). In contrast, if the researcher asks the participant to elaborate and reflect on an experience, this may yield a deeper understanding of what is really going on (Thompson et al., 1989). Such an exploration and probing of customer motivations for SST usage has been identified as a research gap by Etgar (2008).

Most research in multi-channel services is in the retail and banking sector, and often includes the multiple channels of a single retailer (e.g., Schroeder and Zaharia, 2008; Wallace et al., 2004) or bank (e.g., Hsieh et al., 2012; Van Birgelen et al., 2006). Customer motives for channel preferences still need to be researched for other multi-channel situations, such as when price and selection differ across channels (Schroeder and Zaharia, 2008) or when multiple channels and multiple retailers are available to the customer (Neslin and Shankar, 2009). Since multi-channel research has predominantly studied the multiple channels of one company, there is a necessity to understand the effect of both multi-channel and multi-company environments on customer behaviour (Larivière et al., 2011; Neslin and Shankar, 2009). The question is do customers choose channels or firms first? (Neslin and Shankar, 2009). There are still a number of gaps in the multi-channel literature regarding customer behaviour (Dholakia et al., 2010). Bergman and Thelen (2004) suggest that little is known about how failure in one channel affects the usage of other channels or abandoning the firm. 
Other important questions for multi-channel research are suggested by Neslin and Shankar (2009), including what are the best criteria for multi-channel customer segmentation, and the issue of 'right-channelling' customers, i.e., encouraging or forcing them to interact with certain channels. In an SST context, the phenomenon of leaving customers only with an SST option is termed 'forced usage' by Reinders et al. (2008, p.107). Their quantitative research in a rail ticket purchasing context found that providing customers with only an SST option may lead to negative attitudes towards the SST and the service company. Those negative attitudes were the reason for higher switching intentions and negative word-of-mouth (Reinders et al., 2008). Therefore, should channel choice be left to self-selection, or encouraged through incentives (Neslin and Shankar, 2009)? Overall, there appear to be numerous gaps regarding the customer behaviour and decision making in multi-channel environments. The understanding of customer behaviour in multi-channel services may be guided by considering the interplay between channel dimensions, customer differences, nature of the encounter and marketer interventions (Dholakia et al., 2010).

The above discussion may suggest the integration of SST research as part of the multi-channel strand of services research. Therefore, this paper aims to contribute to both SST and multi-channel research by exploring the customer decision-making process and underlying motivations for SST usage in multi-channel, multi-company hospitality environments. The implications from this research would aid hospitality service companies in maintaining better relationships with their customers by providing the most efficient service delivery channels for their customers' needs.

\section{Research methodology}

This study of customer decision-making processes and motivations for SST usage in multi-channel service environments was part of a larger research project into customer usage of SSTs. The dearth of research on actual customer usage behaviours during SST encounters (Wang et al., 2012) and the numerous calls for qualitative research (Baron et al., 2006; Lin and Chang, 2011) justified the employment of short qualitative interviews as a data collection method (Carson et al., 2001). Specifically, the primary data collection for this study involved short, semi-structured interviews with 133 airline passengers in the departure lounge of an international airport. The use of a short interview technique had been successfully used elsewhere by Wang et al. (2012) who employed short semi-structured interviews of 10-15 minutes at supermarket check-outs, with a view to exploring situational influences for customer choice of personal versus self-service check-out.

The short interview format was designed to focus on the usage experiences, reflections and contextual details, from the point of view of 133 passengers who were in a position to discuss their SST usage in the hospitality and tourism sectors. Specifically, the objective of this stage of the research was to explore customer motivations and their decision-making processes with regard to SST usage. With a view to avoiding any preconceptions, the research included a broad convenience sample in terms of ages, gender and education. The average length of an interview was 5-10 minutes, this being a feature of the dynamic nature of the airport environment. The participants were asked to reflect on their general SST usage, and were encouraged to discuss examples, or 
particularly memorable experiences (positive or negative) with an SST. The demographic characteristics of the convenience sample interviewed are presented in Appendix.

The interviews were transcribed and analysed using an interpretive method of data analysis (Miles and Huberman, 1994). This method of data analysis is not seeking to uncover laws of causality, but rather to capture the essence of a participant's account and to understand the meaning of actions (Goulding, 2005). Kim et al. (2012) included in their research of hospitality SSTs, a wide range of interfaces including ATMs, interactive voice response, online flight check-in, order kiosks, pay-at-the-pump, internet self-help and online bookings. This wide range of SSTs, which may be used in a hospitality context, justified the inclusion of customer SST experiences and did not narrowly refer just to hotel or restaurant environments. Furthermore, Slattery (2002) encourages a definition of the hospitality industry to include other contexts where hospitality may be part of the service provision, such as airports, airplanes, bus stations, ferries, trains, casinos, tourist attractions, theatres, cinemas, education, health clubs and work places. The analysis was aided by the qualitative data analysis software NVivo 9. The following section will present the findings regarding customer decision-making processes and motivations for SST usage in multi-channel environments.

Table 1 Decision-making processes and underlying motives for SST usage/avoidance of SST usage

\begin{tabular}{|c|c|c|}
\hline \multicolumn{2}{|c|}{ Use the SST option } & Avoid the SST option \\
\hline 1 & $\begin{array}{l}\text { Use SSTs when they save time/ provide } \\
\text { access }\end{array}$ & $\begin{array}{l}1 \text { Resort to personal channel when the SST } \\
\text { option fails }\end{array}$ \\
\hline 2 & $\begin{array}{l}\text { SST option is the only channel of service } \\
\text { delivery provided, and the customer has no } \\
\text { choice but to use it }\end{array}$ & $\begin{array}{l}2 \text { Avoid SST if it fails often, or is } \\
\text { inefficient, and personal assistance is } \\
\text { required }\end{array}$ \\
\hline 3 & $\begin{array}{l}\text { Tech-proficient customers may prefer the } \\
\text { SST option }\end{array}$ & $\begin{array}{l}3 \text { Avoid SSTs when the personal contact } \\
\text { with an employee is viewed as part of the } \\
\text { experience }\end{array}$ \\
\hline 4 & $\begin{array}{l}\text { Use the SST when the personal option does } \\
\text { not fulfil the customer's goals }\end{array}$ & $\begin{array}{l}4 \text { The SST option may be undesirable in } \\
\text { situations when access to needed } \\
\text { equipment is hard }\end{array}$ \\
\hline 5 & Use the SST with a 'low price' motive & $\begin{array}{l}5 \text { Avoid the SST when there is risk or } \\
\text { responsibility }\end{array}$ \\
\hline 6 & Use the SST channel with trusted companies & 6 Avoid the SST when in a group \\
\hline 7 & $\begin{array}{l}\text { Combine the benefits of various company } \\
\text { channels }\end{array}$ & \\
\hline 8 & Use SSTs when privacy of purchase is desired & \\
\hline 9 & $\begin{array}{l}\text { Use SSTs when they provide more } \\
\text { independence for the customer }\end{array}$ & \\
\hline 10 & SST usage has become a habit & \\
\hline 11 & $\begin{array}{l}\text { Payment option availability determines SST } \\
\text { channel/company choice }\end{array}$ & \\
\hline
\end{tabular}

Source: The Authors 


\section{Findings}

When reflecting on their usage of SSTs, customers often discussed the other options available to them and their decision making processes and motives for SST usage. Distinctive elements of the decision-making processes will be examined below in turn, supported by selected illustrative quotes from the data. The presented quotes are labelled with unique codes that correspond to interview participants. The codes appear after each quote in the following way: (Int.50.M). This identifies interviewee number 50 who was a male participant. Each decision-making element is discussed in light of the service context conditions and customer reflections. The following findings examine customer decision-making processes and motives for SST usage. These elements are summarised in Table 1.

\subsection{Use SSTs when they save time/provide access}

The most frequently provided motive from the participants in this research for engaging with SSTs was that they provided them with convenience in terms of extended access to services and less time wasted to complete the service. The following quote illustrates the convenience motive of better access to the service which the SST provides:

"It is convenient. I have used it before, I am OK with booking tickets and things like that. But, ahm, it was convenient, especially when we don't live in the city, ahm, travel agents aren't around; it is very handy." (Int.48.M)

When at the service location, customers may employ a similar strategy of opting for the SST because it reduces the time for service delivery in comparison to other company channels:

"I mean, normally I would use self check-in, so, I check-in online. I prefer to check-in online, so I don't have to queue in lines, the less queuing I can do, the better. So, if that means automated services, then great. I much prefer that. The same for hotel bookings and stuff like that, I would do all that online." (Int.51.M)

\subsection{SST option is the only channel of service delivery provided, and the customer has no choice but to use it}

At other times, customer's decision-making vis-a-vis SSTs may be a feature of forced usage when only an SST option is available. For example, the following excerpt from a female participant's interview illustrates the situation when only an SST option is available, accompanied by the customer motivation of using SSTs to obtain quicker service:

"At [airport X], now at the moment, to check into your flight there is just scanning. You just scan your bar code of your itinerary and they just let you through the barrier, so that is much quicker. You don't have to go through and queue up and talk to someone. It is all self-service, put the bar code and go through, which is much quicker and much more efficient, I thought.” (Int.1.F)

Alternatively, forced SST usage may be accompanied by a customer preference for personal contact during service delivery. The interview excerpt below discusses airport 
check-in, following a remark from the participant that she would rather speak to a person at the check-in desk:

\author{
Interviewer: And is there always that opportunity to go and do it [check-in] at \\ the counter? \\ Participant: Not when I did domestic travel at home. They said we had to use \\ the kiosk. International, like I said, I couldn't do it beforehand. We had to use \\ the counter. And really, I like talking to a person. \\ Interviewer: You said you had to use the kiosk. How do you feel about the \\ company that makes you do that?
}

Participant: Hmm...I suppose if I found one that didn't, I would use someone else. [laughter] (Int.9.F)

\title{
5.3 Tech-proficient customers may prefer the SST option
}

Some tech-proficient customers indicated that they prefer the SST option in general for any service, and they would be inclined to use it if it can provide them with the needed service. This was partly motivated by the internal understanding and enjoyment that these customers find in using technology. The following interview quotes illustrate this type of customer decision-making process provided that the needed service is available via an SST:

"I have my smart phone every day, my Kindle most days. I work in IT so two or three different computers every day. And basically, we do pretty much everything through the internet. If we are looking for tickets for a show, or tickets for transport, or whatever it is. Our usual position is just to search the internet and see what we can find before we try anything else." (Int.4.F)

"Ahm, for my family holiday coming up, I go on $2^{\text {nd }}$ of September with my mum and my dad and my sisters and my nephew. And I booked everything, all online. I searched for all the flights, I searched for all the hotels to try and find the best price, the best times. I am a bit of a geek [laughter]." (Int.117.F)

\subsection{Use the SST when the personal option does not fulfil the customer's goals}

When the personal option does not really provide the sought experience, some customers preferred to use the SST option where available. The quote below illustrates the situation when for routine service operations the personal element becomes undesirable as employees are viewed by some customers to be performing machine-like service. This participant's desire for social interaction is not met; therefore, he prefers to deal with the machine as a form of protest:

"Well, it is just sometimes nice not having to talk with a personal teller. Just someone there, they are just shifting the stuff and are bored. It is just sometimes nicer to work with a machine, because you don't have to get any of that feedback from them, from the machine.” (Int.7.M)

If a customer's goal is to get a fast service, but the personal element actually slows the service down, they are motivated to engage with an SST:

"The one downfall, I think, they have is to put your bags and get them onto a plane. You do have to have human interaction. And I think, there is a delay in 
getting your tickets and then getting your bags on board only because of that human interaction.” (Int.92.F)

\subsection{Use the SST with a 'low price' motive}

Financial motives may affect the customer decision-making process in multi-channel environments. The following quote illustrates the strategy of opting for the SST when there is a financial incentive to do so:

"We were in Spain last year for the first time. We went with a package company. And we didn't book, ahm, we went through a travel agency and found that it costs maybe 5 or 6 hundred Euro more than if we did it ourselves. So, we went back to doing it ourselves." (Int.23.M)

Sometimes the low price motive to engage with an SST may be triggered by a financial incentive promoted by the service company. The following quote illustrates how a customer started paying his bills online to avoid banking service charges:

"Ahm, just the mobile, mobile phone top-up. Really, I only started doing that automatically because the [bank X] bank, if you do transactions, you don't pay service charges. So, to avoid the service charges, I have started doing that and I find it convenient enough to do that.” (Int.7.M)

\subsection{Use the SST channel with trusted companies}

Another strategy, which some customers employed, was to use the SST channels of trusted companies only. This strategy was invoked by the online security and privacy concerns of those customers and the motivation to avoid any financial losses. For example:

Participant: I have no problem paying [airline company X] or any of those people when I am buying my ticket, just giving my credit card number and it goes through, and that's it.

Interviewer: But you know those. Yes? Is that what you mean?

Participant: Yes, yes. That's right! I would be a bit worried about dealing with people that I don't know. (Int.8.M)

\subsection{Combine the benefits of various company channels}

SSTs could also be used in combination with other company channels. The channels of this company may not always be 'integrated', i.e., providing the same price and selection across all channels. When customers may capitalise on the differences in offerings across the company channels, they tailor-make their usage approach to maximise the customer benefits and optimise the service outcome. For example, the following excerpt illustrates how the knowledge that a better deal may be available over the phone affects this participant's decision to use the SST:

"I find, ahm, online technology helpful if you are trying to investigate a holiday. You can quickly check and see what is possible and what's not possible. Ahm, you can save time compared to calling somebody, for example. So yeah, in that case it is quite handy. But again, if I come to book a holiday, I don't book it online. I would select the holiday I like, make sure it is available, 
then I will ring the company and then I will also try to get a better deal. Which, invariably, you can.” (Int.47.M)

\subsection{Use SSTs when privacy of purchase is desired}

The desire to be private about ones purchases was another motivation which justified the customer strategy to seek SSTs in such situations. Items of clothing or travel bookings were among the preferred purchases to be kept private. The following example from a shopping context illustrates the strategy of using SSTs in order to maintain privacy:

"A lot of the people like to be private about the stuff they get, don't they? I suppose. I can't think of anything in particular now, but...Even, I suppose, clothes...I buy clothes over in America and get them shipped over. I buy them in bulk from [retailer X] and that kind of thing. When you are clothes shopping, you don't like people staring at you and making you feel uncomfortable, that kind of thing. That's one thing I wouldn't mind.” (Int.14.M)

\subsection{Use SSTs when they provide more independence for the customer}

The SST option may be regarded as providing more independence for the customer in situations when it empowers them to make an independent choice. The underlying motivation for seeking independence is to avoid the financial risk of not obtaining the best deal out there. Furthermore, independence seeking SST customers implied that they possess the needed skill and experience to achieve their goals. For example, below are the comments of a female participant on using online travel booking websites:

"You feel more self-reliant too [booking online], because with a travel agent they might be asked to push a certain hotel or chain, or push a certain airline and so this way you can figure out yourself what is the best deal." (Int.31.F)

\subsection{SST usage has become a habit}

Another strategy for SST usage is to prefer it because it is the familiar option and it requires less effort for the customer. Using an SST option may have even become an automatic choice for some customers. For example:

"I guess, because I have done it several times now for trips and so I've just come to know that that's what you do. You do it on your own, you book everything yourself and you just don't bother with travel agents that much anymore." (Int.39.F)

Another similar illustration of the habitual usage of SSTs is evident in the following interview quote:

"I started off using [airline X] and this made it a habit. And now I do it always that way. Now I booked with [airline Y] because I made the habit to use it with [airline X], I made it a habit for every airplane. If I was booking a flight to America now, I would do that on the internet. I wouldn't go to the travel agent's." (Int.38.M) 


\subsection{Payment option availability determines SST channel/company choice}

Sometimes the payment options on a company's website may be limited and this could be the reason for choosing an intermediary online retailer for the transaction. The following excerpt is from a participant who had problems getting his credit card accepted when purchasing airline tickets:

"And the strange thing is often if you go directly to the airplane websites they cannot accept your credit card but if you go through a search engine, like [company X], they can. It is all to do with credit card requirements." (Int.5.M)

Having examined the decision-making processes and motives for SST usage, the following findings relate to customer avoidance of SST options.

\subsection{Resort to personal channel when the SST option fails}

Some customers, whose initial intention was to use the SST, subsequently resorted to the personal option, because the SST failed and could not provide the service. The following quote illustrates this service situation and the customer's anger that they had to incur extra costs to use the personal channel:

"We are always trying to book our flights online these days, rather than use travel agents. It is always cheaper, but too often the website will crash on us. When we were recently booking some holiday flights, we found that we couldn't get our credit cards to be accepted. Subsequently, had to ring up over the phone, obviously, that costs money and time and then they charge you a booking fee over the telephone. We were a little bit [annoyed] why we were paying additional costs when their website wasn't adequate to handle it." (Int.5.M)

Another participant reflected on his decision-making regarding air travel check-in, and the order of his preferred channels:

"I suppose, my first choice would be online check-in because you can do that from home the day before. If that's not available, I would try and check-in with a kiosk at the airport if that's available. And if all else fails, I will go up to a desk and check-in the old-fashioned way [laughter].” (Int.106.M)

\subsection{Avoid SST if it fails often, or is inefficient, and personal assistance is required}

At times, the SST may not provide the required service in an efficient manner, thus making itself redundant from a customer perspective. Therefore, if customers were not able to deliver the entire service when using the SST option, they may decide to abandon it. For example:

"Ahm, insurances and things like that online, I find really boring. Really tedious, because it gets too long, too many questions and at the end of it you normally have to make a phone call to verify everything and check if you can get a better deal. So, that's one thing what I don't like.” (Int.47.M)

Similar views are expressed by another participant regarding supermarket self-service check-outs: 
"I never can get them working [self-service check-outs in supermarkets], like. You always have to get assistance with them. They are a good idea, it speeds up the whole [process]...like some people use them all the time. I personally, if there are cashiers there, I would use them." (Int.14.M)

\subsection{Avoid SSTs when the personal contact with an employee is viewed as part of the experience}

SST options may be avoided by customers who believe that in certain service situations, the personal touch is part of the experience. The motivation behind SST avoidance appeared to be the desire for social contact and memorable experiences. For example, shops and hotels were suggested as service contexts where the following participant demanded personal contact with an employee:

"Personally, I don't like self-service in shops anywhere. I actually like one-toone contact with a person. I don't like it [self-service]. For certain things, it speeds you up, it makes life easier, but there are other times, I would hate it in a hotel. In certain instances, in shops and in hotels, personal service adds that extra...it is part of it." (Int.15.F)

\subsection{The SST option may be undesirable in situations when access to needed equipment is hard}

Even if customers may prefer the SST option in general, they may evaluate it as inconvenient and try to avoid it in situations when for some reason access to the needed technological equipment may be impeded. For example:

"I am a pretty regular flier and I do use [airline X] from time to time, so I am ready for that. But once, it caught me again last year. I got delayed by an extra day in Bristol airport and I had to rebook a ticket, and of course, I didn't have access to my laptop, printer and all the rest of it. So, that was a bit more awkward to find a place which will let me email them my ticket and get them to let me print off my booking voucher and then go check-in again." (Int.21.M)

\subsection{Avoid the SST when there is risk or responsibility}

The strategy of avoiding the SST option for bigger travel purchases may be justified by the perceived chance of error, which the customer seeks to avoid. Ultimately the customer's motive for avoiding the SST option is the desire to minimise financial risk. For example:

"Now we did go on a honeymoon at Christmas, so we did book it through travel agents just for the fact we didn't want to lose any portion of going anywhere... we booked big flights. We were in Australia for, I suppose, about two months, so we did book those through travel agents. I'd say more shorthaul flights, you would just book yourself. Definitely if I am going somewhere for a long time, and you just want to have the back up there if something goes wrong." (Int.116.F)

"I booked the flight through a travel agent because after the volcano in Iceland, there is no come back if you do it yourself. So, we changed back to the travel agent. Before that, we used to do it ourselves." (Int.49.M) 


\title{
5.17 Avoid the SST when in a group
}

Customers may sometimes opt for personal service if they are travelling in a group. They may comply with the group decision because someone else is in charge, or to avoid negotiations. For example:

\begin{abstract}
Participant: I wanted to use the kiosk when we checked-in, but my parents refused to use it. They don't understand it as well as we do. So, it's, I guess, harder for them. They don't like to use it as much. It comes easily to me, I don't know. It makes things faster for me, but they don't like using it.

Interviewer: So, you just didn't use them because they didn't want to...?

Participant: They didn't use them and she [mother] has the passports, she is in charge. [laughter] (Int.65.F)
\end{abstract}

\section{Discussion}

The objective of this research was to explore the customer decision-making processes and underlying motivations for SST usage in mult-ichannel, multi-company hospitality environments. The findings of this research contribute towards an understanding of customer behaviour in multi-channel services and have implications for customer relationship building in electronic service channels. Customer decisions to engage with an SST option were examined in a particular service context and clarified by participants' reflections on their choices.

On the occasions when customers used the SST options, their motivations and goals included gaining access to a service, saving time and money, avoiding financial risk, independence, privacy of purchase, trust in the service company, enjoyment and utilising less effort. Some of these motives have been identified elsewhere in the SST literature, i.e. save time and money, better access (Dabholkar et al., 2003; Meuter et al., 2000) and multi-channel research, i.e., independence and convenience (Schroeder and Zaharia, 2008). The contribution of this paper is to clarify the service conditions under which those motives influence the decision-making for customer engagement with SSTs in the contemporary hospitality industry. For example, some SST users may experience an internal enjoyment from the technology-human interaction (Dabholkar et al., 2003), provided that those customers are generally highly tech-proficient and the SST is preferably online. Furthermore, independence may act as a motivator in the sense of a freedom to customise the service and complete the transaction at the customer's convenience (Liljander et al., 2006). Our findings suggest that for some customers, independence may motivate them to use SSTs because they can receive independent service offers, in comparison to a travel agent who may promote a certain company. The condition for customers to seek such independence is that they believe they know how to compare service offerings and fulfil their goals. The ultimate motivation of those customers then is the avoidance of financial risk, i.e., purchasing more expensive and less attractive services. Therefore, while product risk avoidance has been found to de-motivate customers from using electronic channels (Schroeder and Zaharia, 2008), this research uncovered that the desire to avoid the financial risk of purchasing a more expensive service, may motivate hospitality customers to actually use SSTs. 
This paper provides evidence for the existence of other customer motivations for SST usage, which have not been discussed in the SST and multi-channel literature. One customer motive for SST usage appeared to be the desire for privacy of purchase, especially for personal items. At times, customers may resort to the SST option not because they hold a negative attitude in general towards personal service or want to avoid it (Curran and Meuter, 2007; Dabholkar et al., 2003), but because it does not fulfil their goals of genuine social interaction, or obtaining fast service. Therefore, the SST option may be used by some customers to protest against personal service disappointments, and not because of a desire to avoid personal contact. Furthermore, some customers were motivated to use an SST option because of their trusted relationship with the service provider. Insufficient trust in the service company was found to be a de-motivator for SST usage in Liljander et al. (2006), to which our research adds, by suggesting that alternatively a good trusting relationship may become a motivator for SST usage. Finally, some customers used the SST option to avoid extra customer effort in decision-making. Liljander et al. (2006) suggest that customers may avoid SSTs because they do not want to put the effort into learning how to operate it and changing their customer behaviour, for the same reason customers who have built the habit of SST usage may opt for it automatically. Such customers would not notice even if all other service options are removed because their decision-making process omits the stage of channel comparisons. This has important implications for companies who wish to remove large numbers of their customer-contact employees and to introduce more SSTs.

In relation to understanding customer decision-making processes which lead to avoidance of the SST option, this paper adds to previous research by Dabholkar et al. (2003), Liljander et al. (2006), Meuter et al. (2000, 2003). Firstly, service failures are one of the biggest de-motivators for customers to continue SST usage (Meuter et al., 2000; Wang et al., 2012) which was further confirmed in this research. SST failures force customers to resort to personal or e-mail contact with the service company to receive a refund or obtain the service. If the SST fails often, or it does not provide for the customer to complete the transaction without employee assistance, such SSTs were perceived as redundant and were eventually avoided. The de-motivators of anxiety (Meuter et al., 2003), embarrassment (Forbes, 2008) and the inconvenience of learning how to operate the SST (Liljander et al., 2006) did not appear to be very influential in this research partly because of the sampling criteria for participants to have some SST usage experience. The desire for personal contact and social interaction during services is another de-motivator for SST usage in general (Dabholkar et al., 2003). In the traditional hospitality context, SST avoidance is further strengthened by the customer perception that the personal element is an ingredient of the service experience. Even customers, who did not indicate the need for personal interaction in other service occasions, did suggest that the removal of personal service in hospitality environments would be unusual. Therefore, it appears that the image of hospitality as a people industry acts as an inhibitor in the customer decision to embrace more SSTs. In saying this, SSTs may be introduced for most aspects of the hospitality service while the personal element remains visible in those environments. In line with previous research (Wang et al., 2012), other people accompanying the customer could influence their decision-making. But while Wang et al. (2012) confirmed a positive influence of shopping companions on the decision of the customer to interact with self check-outs in supermarkets, our findings also suggest the possibility of a negative influence if the person in charge of the group has decided against SST usage. A further de-motivator for SST usage could be the limited accessibility to 
technological equipment to use the SST option at the time. Particularly when travelling, customers may not have internet access, or indeed, access to computer and printer facilities, which could make the SST option very arduous. Finally, customers may wish to avoid SST usage if they feel that they are taking on extra responsibility and tasks which may carry financial risks to them. An example of this might be an accidental doublebooking on a hotel website.

\section{$7 \quad$ Limitations and further research}

While this research provided valuable insights into the SST user decision-making process and motivations, there are limitations to its scope. Firstly, the context of this study was the broader hospitality industry; therefore, in-depth research in a specific hospitality sector may provide further understanding of the presented findings. Secondly, the desire to capture a multitude of diverse perspectives from customers first hand justified the choice of an airport as a research location. A downside to this approach was the limited length of the interviews and respectively the depth of the discussion. Longer in-depth interviews could provide an opportunity to build a more complete and detailed description of the experienced service situations, and thus provide a better understanding of customer decision-making processes. Future research may apply the findings from this study in constructing and clarifying variables for quantitative research projects. Such projects may provide knowledge of the influential power of customer SST usage motivations in various hospitality settings. Furthermore, quantitative research may explore potential mediating influences of demographic variables on the power of certain motivations for SST usage.

\section{References}

Baron, S., Patterson, A. and Harris, K. (2006) 'Beyond technology acceptance: understanding consumer practice', International Journal of Service Industry Management, Vol. 17, No. 2, pp.111-135.

Bergman, B. and Thelen, S. (2004) 'A guide to developing and managing a well-integrated multi-channel retail strategy', International Journal of Retail and Distribution Management, Vol. 32, No. 3, pp.147-156.

Buhalis, D. and Law, R. (2008) 'Progress in information technology and tourism management: 20 years on and 10 years after the internet - the state of eTourism research', Tourism Management, Vol. 29, No. 4, pp.609-623.

Carson, D., Gilmore, A., Perry, C. and Gronhaug, K. (2001) Qualitative Marketing Research, Sage, London.

Castro, D., Atkinson, R. and Ezell, S. (2010) Embracing the Self-Service Economy, April, The Information Technology and Innovation Foundation, Washington.

Chatterjee, P. (2007) 'Cross-channel product ordering and payment policies in multichannel retailing: implications for shopping behavior and retailer profitability', Journal of Shopping Center Research, Vol. 13, No. 2, pp.31-56.

Curran, J. and Meuter, M. (2005) 'Self-service technology adoption: comparing three technologies', Journal of Services Marketing, Vol. 19, No. 2, pp.103-113.

Curran, J. and Meuter, M. (2007) 'Encouraging existing customers to switch to self-service technologies: put a little fun in their lives', Journal of Marketing Theory and Practice, Vol. 15, No. 4, pp.238-298. 
Curran, J., Meuter, M. and Surprenant, C. (2003) 'Intentions to use self-service technologies: a confluence of multiple attitudes', Journal of Service Research, Vol. 5, No. 3, pp.209-224.

Dabholkar, P. and Bagozzi, R. (2002) 'An attitudinal model of technology-based self-service moderating effects of consumer traits and situational factors', Journal of the Academy of Marketing Science, Vol. 30, No. 3, pp.184-201.

Dabholkar, P., Bobbitt, L. and Lee, E. (2003) 'Understanding consumer motivation and behavior related to self-scanning in retailing', International Journal of Service Industry Management, Vol. 14, No. 1, pp.59-95.

Dean, D. (2008) 'Shopper age and the use of self-service technologies', Managing Service Quality, Vol. 18, No. 3, pp.225-238.

Dholakia, U., Kahn, B., Reeves, R., Rindfleisch, A., Stewart, D. and Taylor, E. (2010) 'Consumer behavior in a multichannel, multimedia retailing environment', Journal of Interactive Marketing, Vol. 24, No. 2, pp.86-95.

Egger, R. and Buhalis, D. (2008) Etourism Case Studies, Butterworth Heinemann, Oxford.

Etgar, M. (2008) 'A descriptive model of the consumer co-production process', Journal of the Academy of Marketing Science, Vol. 36, No. 1, pp.97-108.

Forbes, L. (2008) 'When something goes wrong and no one is around: non-internet self-service technology failure and recovery', Journal of Services Marketing, Vol. 22, No. 4, pp.316-327.

Gelderman, C., Ghijsen, P. and Diemen, R. (2011) 'Choosing self-service technologies or interpersonal services - the impact of situational factors and technology-related attitudes', Journal of Retailing and Consumer Services, Vol. 18, No. 5, pp.414-421.

Goulding, C. (2005) 'Grounded theory, ethnography and phenomenology: a comparative analysis of three qualitative strategies for marketing research', European Journal of Marketing, Vol. 39, Nos. 3/4, pp.294-308.

Hsieh, Y., Roan, J., Pant, A., Hsieh, J., Chen, W., Lee, M. and Chiu, H. (2012) 'All for one but does one strategy work for all? Building consumer loyalty in multi-channel distribution', Managing Service Quality, Vol. 22, No. 3, pp.310-335.

Kelly, P., Lawlor, J. and Mulvey, M. (2011) 'A review of key factors affecting consumers' adoption and usage of self-service technologies in the tourism sector', in O'Connell, K. et al. (Eds.): Tourism and Hospitality Research in Ireland: Current Challenges and Future Opportunities, pp.122-140, NUI Galway and Shannon College of Hotel Management.

Kim, J., Christodoulidou, N. and Brewer, P. (2012) 'Impact of individual differences and consumers' readiness on likelihood of using self-service technologies at hospitality settings', Journal of Hospitality and Tourism Research, Vol. 26, No. 1, pp.85-114.

Larivière, B., Aksoy, L., Cooil, B. and Keiningham, T. (2011) 'Does satisfaction matter more if a multichannel customer is also a multicompany customer?', Journal of Service Management, Vol. 22, No. 1, pp.39-66.

Lee, H., Cho, H., Xu, W. and Fairhurst, A. (2010) 'The influence of consumer traits and demographics on intention to use retail self-service checkouts', Marketing Intelligence and Planning, Vol. 28, No. 1, pp.46-58.

Lee, J. and Allaway, A. (2002) 'Effects of personal control on adoption of self-service technology innovations', Journal of Services Marketing, Vol. 16, No. 6, pp.553-573.

Liljander, V., Gillberg, F., Gummerus, J. and Riel, A. (2006) 'Technology readiness and the evaluation and adoption of self-service technologies', Journal of Retailing and Consumer Services, Vol. 13, No. 3, pp.177-191.

Lin, J. and Chang, H. (2011) 'The role of technology readiness in self-service technology acceptance', Managing Service Quality, Vol. 21, No. 4, pp.424-444.

Lin, J. and Hsieh, P. (2007) 'The influence of technology readiness on satisfaction and behavioral intentions toward self-service technologies', Computers in Human Behavior, Vol. 23, No. 3, pp.1597-1615. 
Meuter, M., Bitner, M., Ostrom, A. and Brown, S. (2005) 'Choosing among alternative service delivery modes: an investigation of customer trial of self-service technologies', Journal of Marketing, April, Vol. 69, No. 2, pp.61-83.

Meuter, M., Ostrom, A., Bitner, M. and Roundtree, R. (2003) 'The influence of technology anxiety on consumer use and experiences with self-service technologies', Journal of Business Research, Vol. 56, No. 11, pp.899-906.

Meuter, M., Ostrom, A., Roundtree, R. and Bitner, M. (2000) 'Self-service technologies: understanding customer satisfaction with technology-based service encounters', Journal of Marketing, July, Vol. 64, No. 3, pp.50-64.

Miles, M. and Huberman, M. (1994) Qualitative Data Analysis, 2nd ed., Sage, Thousand Oaks, CA.

Neslin, S. and Shankar, V. (2009) 'Key issues in multichannel customer management: current knowledge and future direction', Journal of Interactive Marketing, Vol. 23, No. 1, pp.70-81.

Nilsson, D. (2007) 'A cross-cultural comparison of self-service technology use', European Journal of Marketing, Vol. 41, Nos. 3/4, pp.367-381.

Reinders, M., Dabholkar, P. and Frambach, R. (2008) 'Consequences of forcing consumers to use technology-based self-service', Journal of Service Research, November, Vol. 11, No. 2, pp.107-123.

Schroeder, H. and Zaharia, S. (2008) 'Linking multi-channel customer behavior with shopping motives: an empirical investigation of a German retailer', Journal of Retailing and Consumer Services, Vol. 15, No. 6, pp.452-468.

Simon, F. and Usunier, J. (2007) 'Cognitive, demographic, and situational determinants of service customer preference for personnel-in-contact over self-service technology', International Journal of Research in Marketing, Vol. 24, No. 2, pp.163-173.

Slattery, P. (2002) 'Finding the hospitality industry', Journal of Hospitality, Leisure, Sport and Tourism Education, Vol. 1, No. 1, pp.19-28.

Thompson, C., Locander, W. and Pollio, H. (1989) 'Putting consumer experience back into consumer research: the philosophy and method of existential-phenomenology', Journal of Consumer Research, Vol. 16, No. 2, pp.133-146.

Van Birgelen, M., de Jong, A. and de Ruyter, K. (2006) 'Multi-channel service retailing: the effects of channel performance satisfaction on behavioral intentions', Journal of Retailing, Vol. 82, No. 4, pp.367-377.

Walker, R. and Johnson, L. (2006) 'Why consumers use and do not use technology-enabled services', Journal of Services Marketing, Vol. 20, No. 2, pp.125-135.

Wallace, D., Giese, J. and Johnson, J. (2004) 'Customer retailer loyalty in the context of multiple channel strategies', Journal of Retailing, Vol. 80, No. 4, pp.249-263.

Wang, C., Harris, J. and Patterson, P. (2012) 'Customer choice of self-service technology: the role of situational influences and past experience', Journal of Service Management, Vol. 23, No. 1, pp.54-78. 


\section{Appendix}

Demographic characteristics of the sample

\begin{tabular}{|c|c|c|c|c|c|c|}
\hline Gender & $\begin{array}{c}\text { Age } \\
\text { (years) }\end{array}$ & Age \% & Education & Education \% & Nationality & Nationality $\%$ \\
\hline \multicolumn{7}{|l|}{ Male } \\
\hline 69 & $18-24$ & $20.29 \%$ & Primary & $1.45 \%$ & IRL & $44.93 \%$ \\
\hline \multirow[t]{8}{*}{$51.88 \%$} & $25-34$ & $23.19 \%$ & High School & $36.23 \%$ & UK & $20.29 \%$ \\
\hline & $35-44$ & $15.94 \%$ & BA & $33.33 \%$ & USA & $20.29 \%$ \\
\hline & $45-54$ & $17.39 \%$ & MA over & $28.99 \%$ & FR & $10.14 \%$ \\
\hline & $55-64$ & $21.74 \%$ & & & AUS & $1.45 \%$ \\
\hline & 65 over & $1.45 \%$ & & & SP & $0.00 \%$ \\
\hline & & & & & MAURITIUS & $0.00 \%$ \\
\hline & & & & & GER & $1.45 \%$ \\
\hline & & & & & POL & $1.45 \%$ \\
\hline Male total & & $100.00 \%$ & & $100.00 \%$ & & $100.00 \%$ \\
\hline \multicolumn{7}{|l|}{ Female } \\
\hline 64 & $18-24$ & $25.00 \%$ & Primary & $1.56 \%$ & IRL & $42.19 \%$ \\
\hline \multirow[t]{8}{*}{$48.12 \%$} & $25-34$ & $28.13 \%$ & High school & $37.50 \%$ & UK & $21.88 \%$ \\
\hline & $35-44$ & $7.81 \%$ & BA & $34.38 \%$ & USA & $26.56 \%$ \\
\hline & $45-54$ & $17.19 \%$ & MA over & $26.56 \%$ & FR & $3.13 \%$ \\
\hline & $55-64$ & $17.19 \%$ & & & AUS & $1.56 \%$ \\
\hline & 65 over & $4.69 \%$ & & & SP & $1.56 \%$ \\
\hline & & & & & MAURITIUS & $1.56 \%$ \\
\hline & & & & & GER & $0.00 \%$ \\
\hline & & & & & POL & $1.56 \%$ \\
\hline Female total & & $100.00 \%$ & & $100.00 \%$ & & $100.00 \%$ \\
\hline
\end{tabular}

